\title{
反対咬合者の下顎の前方偏位が咀嚼筋活動に及ぼす影響 について
}

Electoromyographic study on masticatory muscle activity of functional class III malocclusion

\author{
○篠田充巨、、松野 功、今井徹、中村進治 \\ OMitsunao Shinoda, Isao Matsuno, Tohru Imai, Shinji Nakamura \\ 北海道大学歯学部歯科矯正学講座 \\ Department of Orthodontics, School of Dentistry, Hokkaido University
}

1.はじめに

矯正治療を受ける患者の中で最も多い反対咬 合では、咬頭嵌合位に至る下影の運動路上に上 下影前歯部の早期接触が有り、その誘導により 下䂓が機能的に前力へ偏位する症例が多く認め られる。しかし、この下影の前方偏位が咀罚筋 活動にどのような影響を及ぼしているのかにつ いては明かにされていない。

そこで本赛験は、これを明らかにするため に、反対咬合者と正常咬合者における下疑位を 前後的に変化させることによって、咬筋全域の 筋活動に及ぼす影響を調べた。さらに、下顆か 機能的に前方偏位する反対咬合者の矯正治療に よる下頻位の変化が、咬筋筋活動に及ほす影響 についても調べた。

\section{2. 方法}

本研究では反対咬合者を2つに分け、切端咬 合可能な者を機能性反対咬合者群とし、切端咬 台不可能な者を骨格性反対咬合者群とした。被 験者の内訳は、機能性反対咬合者群8名(男子 2名、女子 6 名、平均年齢9才5 月）、骨格 性反対咬合者群 3 名(男子2名、女子1名、平 均年噛7才11ケ月)であった。また、対照とし て小児正常咬合者群男子 3 名（平均年齢 9 才 1 ケ月）と、成人正常咬合者群男子 3 名（平均年 跉27才4ケ月)を用いた。

本実験において設定した下頻位は、以下の 5 つとした。咬頭嵌合位：ICP、打よびゴシッ

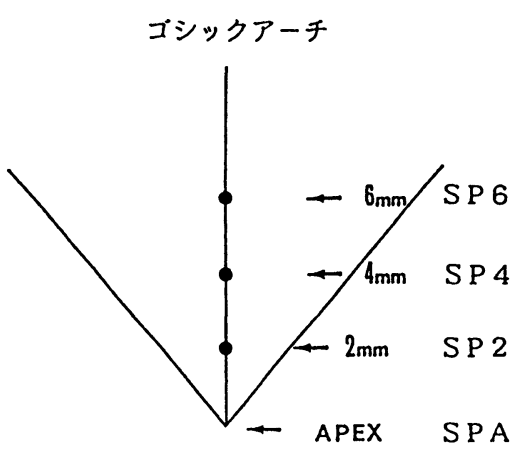

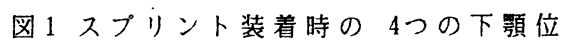

ク・アーチの前方滑走路上のアペックス、なら びにアペックスから $2 \mathrm{~mm} 、 4 \mathrm{~mm} 、 6 \mathrm{~mm}$ 前方の 4 つの位置で作䳤したスプリント装着時の下影位 であり、それぞれSPA、SP2、SP4、SP6とし た（図1）。下頻位を規定し安定した上下粷列の 咬合接触関係を得るために、スプリントは即時 重合レジンで作製し、臼歯部では咬合面全体を 復い、犬歯を含めた前止部は唇舌面の歯冠側約 1/5までとした。また、上下的な厚さはコシッ ク・アーチの描記板と描記針により規定される 範囲で最小とし第一大臼歯部で $3 \sim 5 \mathrm{~mm}$ とし た。

被験筋は左右咬筋とし、設定した 5 つの下顮 位について、頻度毎分約 30 回で持続時間約 2 秒 の最大かみしめを6 回ずつ行なわせ、筋電図を 記録した。この際、ペースメーカーとしてLED の点隇を用いた。

筋電困記録時期は、機能性反対咬合者群で は、ステージIとして治療開始前、ステージ II 


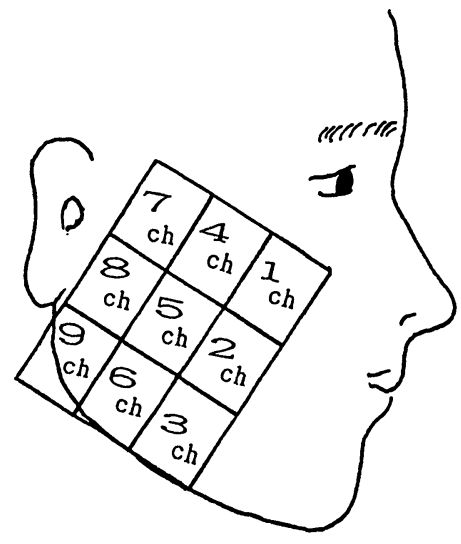

図2 電極板の貼付位置とチャンネル番号の関係

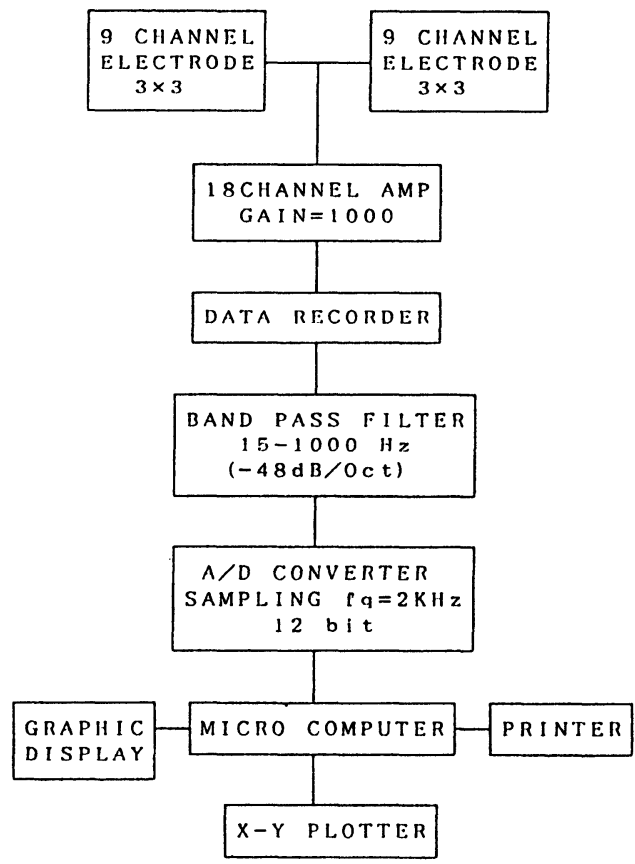

図3 筋電図分析システムのブロックタイアグラム

としてSPA のスプリントをステージ 以後 7〜 14日装着後、さらにステージII として被蓋改善 後の、合計 3 ステージとした。骨格性反対咬合 者群は、ステージI、II の合計 2ステージで記 録し、小児正常咬合者群と成人正常咬合者群は それぞれステージIに相当する時期のみ記録し た。

電極は、直径 $4 \mathrm{~m}$ nの 銀一塩化銀表面電極（日 栄計測社製）を用い、絴に $15 \mathrm{~mm}$ 間隔で 4 個、横 に $15 \mathrm{~mm}$ 間隔で 3 個、合計 12 個を格子状に配列し

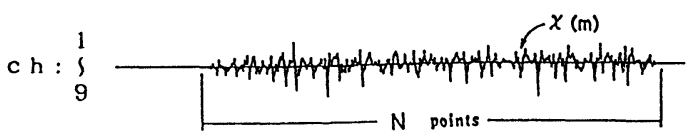

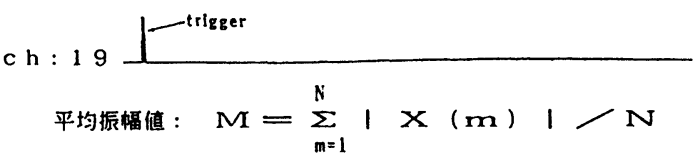

四4 各チャンネルの平均振幅値の算出法

て、絴 1列 4 個を隣り合った双極で 3 チャンネ ルずつ誘導して、左右咬筋全域の筋電図”をそ れぞれ9チャンネルで記録した。電極板の貼付 位置は、触診により確認した咬咜後緑と下額骨 下縁をそれぞれ、電極板後縁と下縁に一致させ た（図2)。チャンネル番号は、左右咬能の上前 方部から下後方部までをそれぞれ、1〜9チャ ンネルとした。なお、不感電極は前額部に設定 した。

図 3 に、筋電図分析システムのブロックタイ アグラムを示す。左右 9 チャンネルダつ同時 に、合計18チャンネルで導出された筇電図波形 は、高入カインピータンスの差動型增幅器（時 定数：0.15 m sec 原田電子工業社製) で 1000 倍 に增幅し、データレコータ（TEAC社製XR-710） に9. $5 \mathrm{~cm} / \mathrm{sec}$ のテープスピードで収録した。収 録した筋電図波形を、低域遮断周波数 $15 \mathrm{~Hz}$ 、高 域遮断周波数 $1 \mathrm{KHz}$ 、隇衰特性 $-48 \mathrm{~dB} / 0 \mathrm{ct}$ のバン ドパスフィルター（エヌエフ回路設計ブロック 社製FV-625A）に通した後、マイクロコンピュ 一タ（BUG 社製Staff）を用いて、サンプリング 周波数 $2 \mathrm{KHz}$ 、精度 $12 \mathrm{bit}$ で量子化し演算処理を 行ない、結果をグラフィックディスプレイ等に 出力した。また、筋電困の記録は全てシールド ルーム内で行なった。

図4に各チャンネルにおける筋活動量を表わ すために設定した、平均振幅值の算出法を示 す。左右それぞれ9チャンネルの筋電図波形の 時間軸を合わす基準点として、データレコーダ の19チャンネルに記録したトリガー信号を用い た。チャンネルごとに筋電図データを時系列関 数Xで表わし、N 個の振幅值を絶対値化して加 算し、ポイント数 $\mathrm{N} て ゙$ 割った值を平均振幅值 $\mathrm{M}$ として算出した。次に、下頻位の変化に対する 筋活動量の変化の割合を、チャンネル間で同一 の基準で比較するために、相対的活動量を以下 

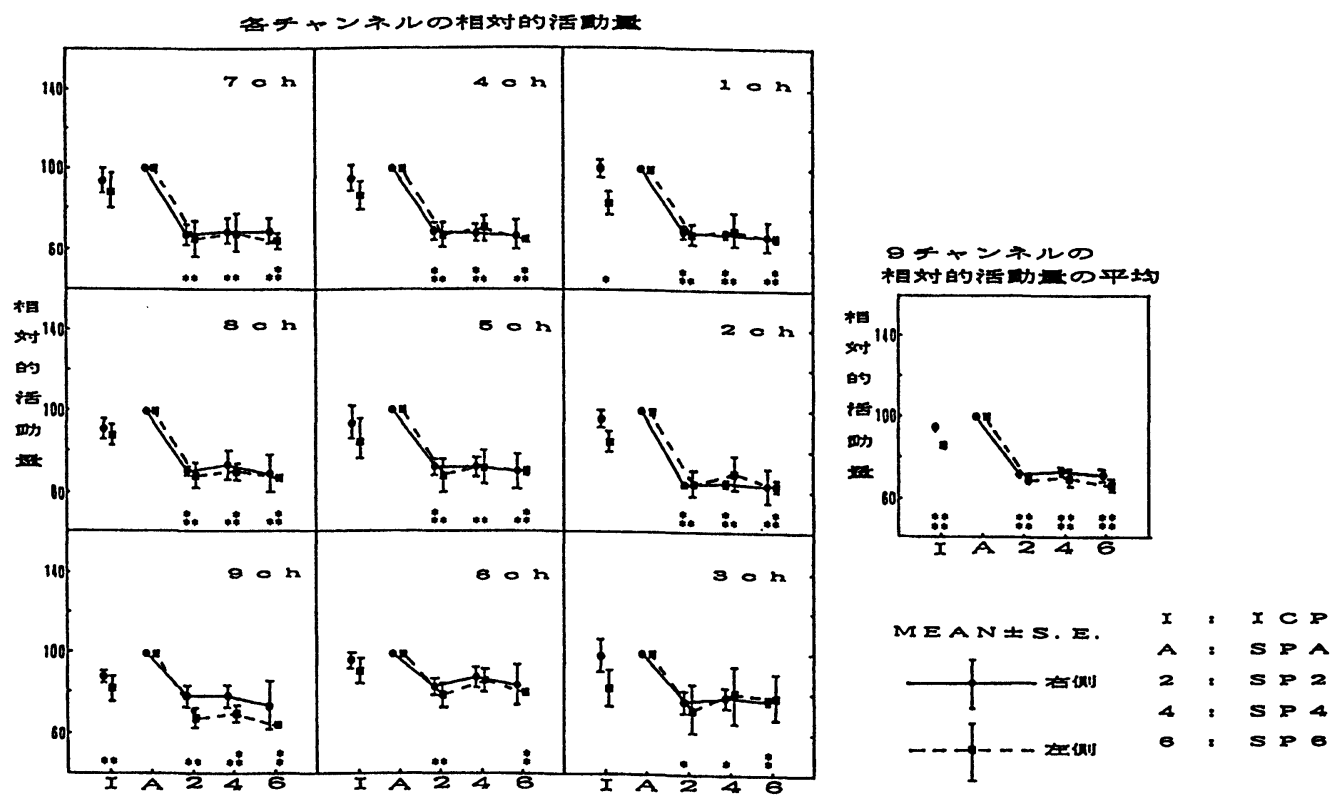

図5 成人正常咬合者 3 名の相対的活動

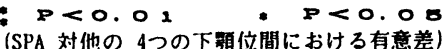

の演算により求めた。

$$
\begin{array}{r}
\text { 相对的活動量：R } j=\frac{M j}{M \text { SPA }} \times 100 \\
(j=I C P, S P A, S P 2, S P 4, S P 6)
\end{array}
$$

相対的活動量 R j は、チャンネルごとに各 下額位の平均振幅值 $M j$ を、SPA の平均振幅 値M SPA で割り100を掛た值として求めた。

\section{3. 結果}

\section{1 正常咬合者}

図 5 に、成人正常咬合者群 3 名における相対 的活動量の平均値と標準䛊差を示す。左右とも にほとんどのチャンネルに拀いてSPAで最も筋 活動量か大きく、次にICPで大きく、SP2、SP4、 SP6 では、SPA に対して有意に小さい傾向が認 められた。

図6に、小児正常咬合者群 3 名の相対的活動 量を示す。成人正常咬合者群と同様、左右とも にほとんどのチャンネルにおいてSPAで最も筋 活動量が大きく、次にICPで大きく、SP2、SP4、 SP6では、SPA に対して有意に小さい傾向が認 められた。しかし、SPA からSPGまでの笳活動 量の変化は、成人正常咬合者群とは異なり徐々
に減少する傾向が認められた。

\section{2 反対咬合者}

図7に、骨格性反対咬合者群3名のステージ Iでの相対的活動量を示す。成人正常咬合者群 小児正常咬合者群と同様、左右ともにほとん どのチャンネルにおいてSPA で最も大きな筋活 動量を示す傾向が認められた。しかし、SPA か 5SP6 までの筋活動量の变化は、小児正常咬合 者群と類似し徐々に隇少する傾向を示した。

図8に骨格性反対咬合者群3名のステージII での相対的活動量を示す。ステージI と同じく SPA で最も筋活動量が大きく、SPA からSP6 での筋活動量の変化では、両ステージで明確な 差異は認められなかった。

図 9 に、機能性反対咬合者群 8 名のステーシ Iでの相対的活動量を示す。SPA からSP6まで の下額位の中で、左右ともに全チャンネルにお いてSP2 が最も大きな筋活動量を示し、SP2 の 前後で筋活動量が徐々に減少する傾向が認めら れ、先の 3 群とは明らかに異なっていた。

図10に、機能性反対咬合者群8名のステージ II での相対的筋活動量を示す。ステージIとは 異なり、SPA が最も筋活動量か大きくなってい るという変化が認められた。SPAからSP6まで 

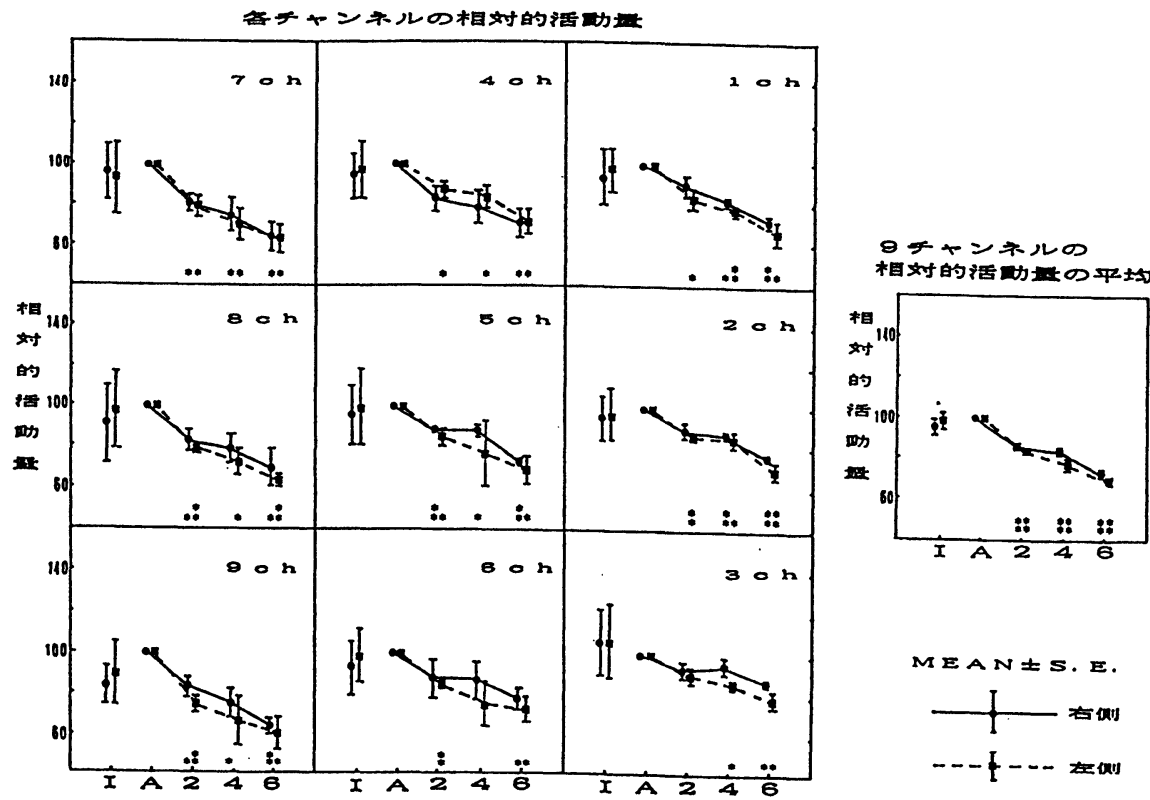

図6 小肾正常咬合者 3名の相対的活動量
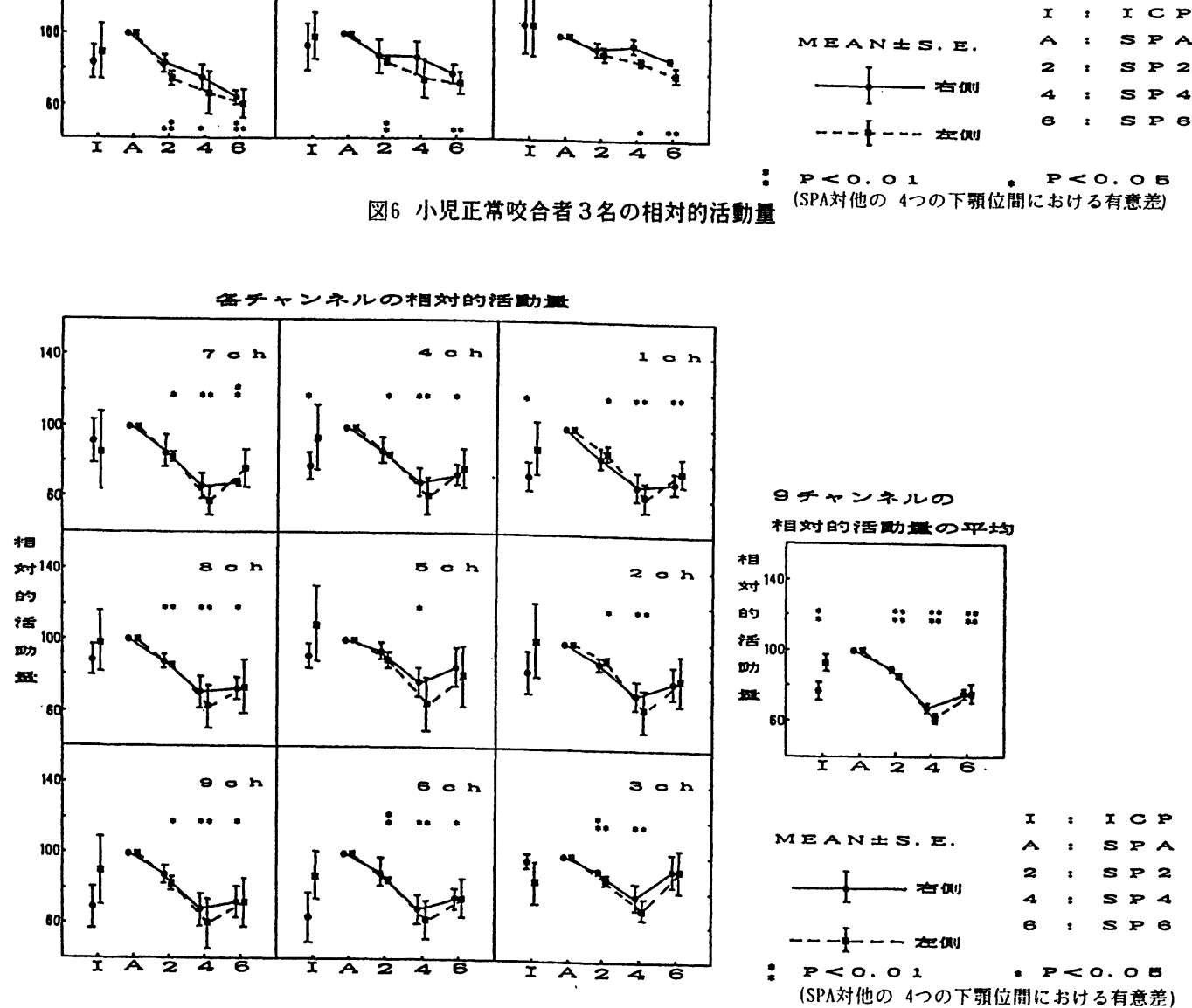

図7骨格性反対咬合者 3名のステージI での相対的活動量

の筋活動量の変化量は小さいが徐々に隇少する 傾向加認られ、小児正常咬合者群に類似してい た。

図11に、機能性反対咬合者群8名のステージ IIIでの相対的活動量を示す。SPAで最も筋活動
量が大きく、SP2、SP4、SP6 では、筋活動量が全 てのチャンネルで有意に小さくなる傾问が認め られた。この変化の傾向は先に示した小児正常 咬合者群に非常に類似していた。 


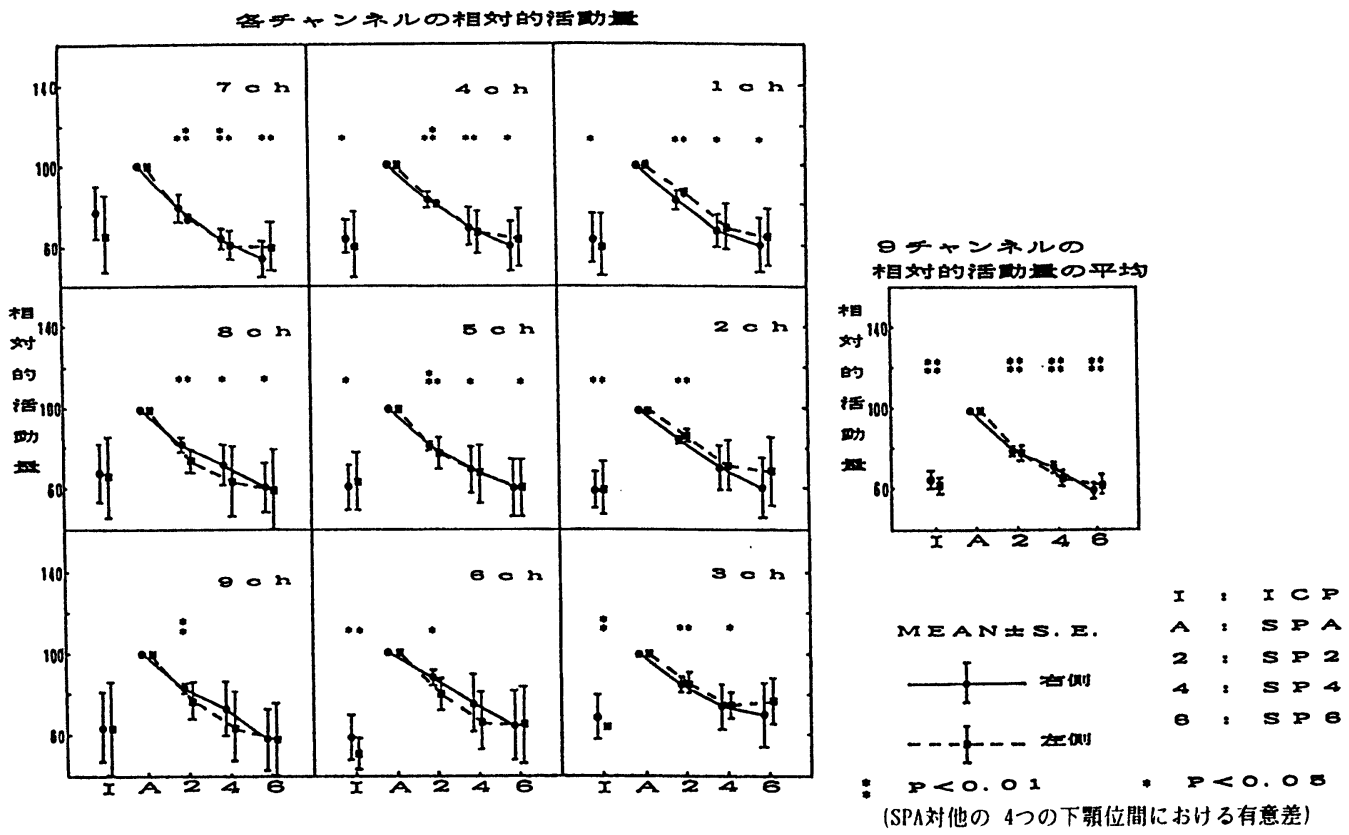

図8 骨格性反対咬合者 3名のステージ П での相対的活動量
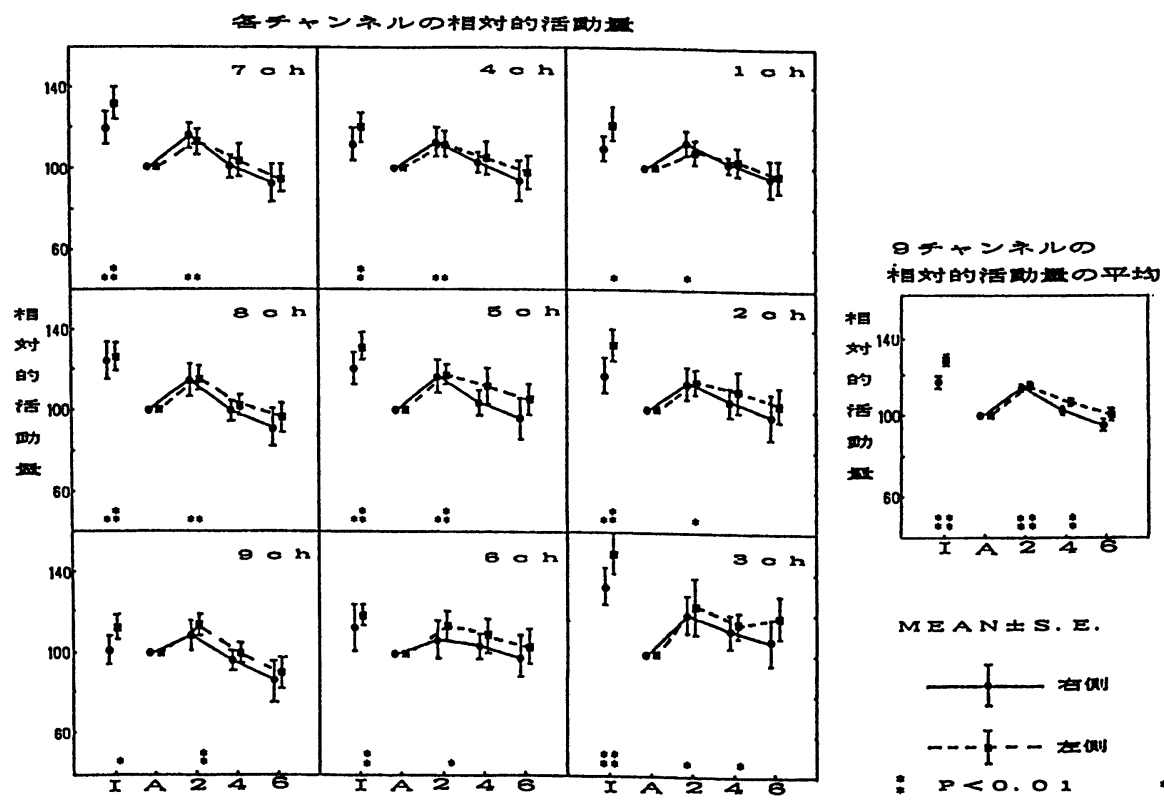

図9 機能性反対咬合者 8名のステージI での相対的活動量

4. 考察

4.1 正常咬合者

一般に、成人において下頻位が前方に変化す ると、咬みしめ時における咀喘筋活動量が減少
するといわれている2、31。本実験でも、下䫓が 前方位をとるに従い咬笳筋活動量は減少した。 しかし、成人正常咬合者群のSPA からSP6 まで の筋活動量の変化はSP2 で急激に減少するのに 対して、小児正常咬合者群では徐々に減少する 


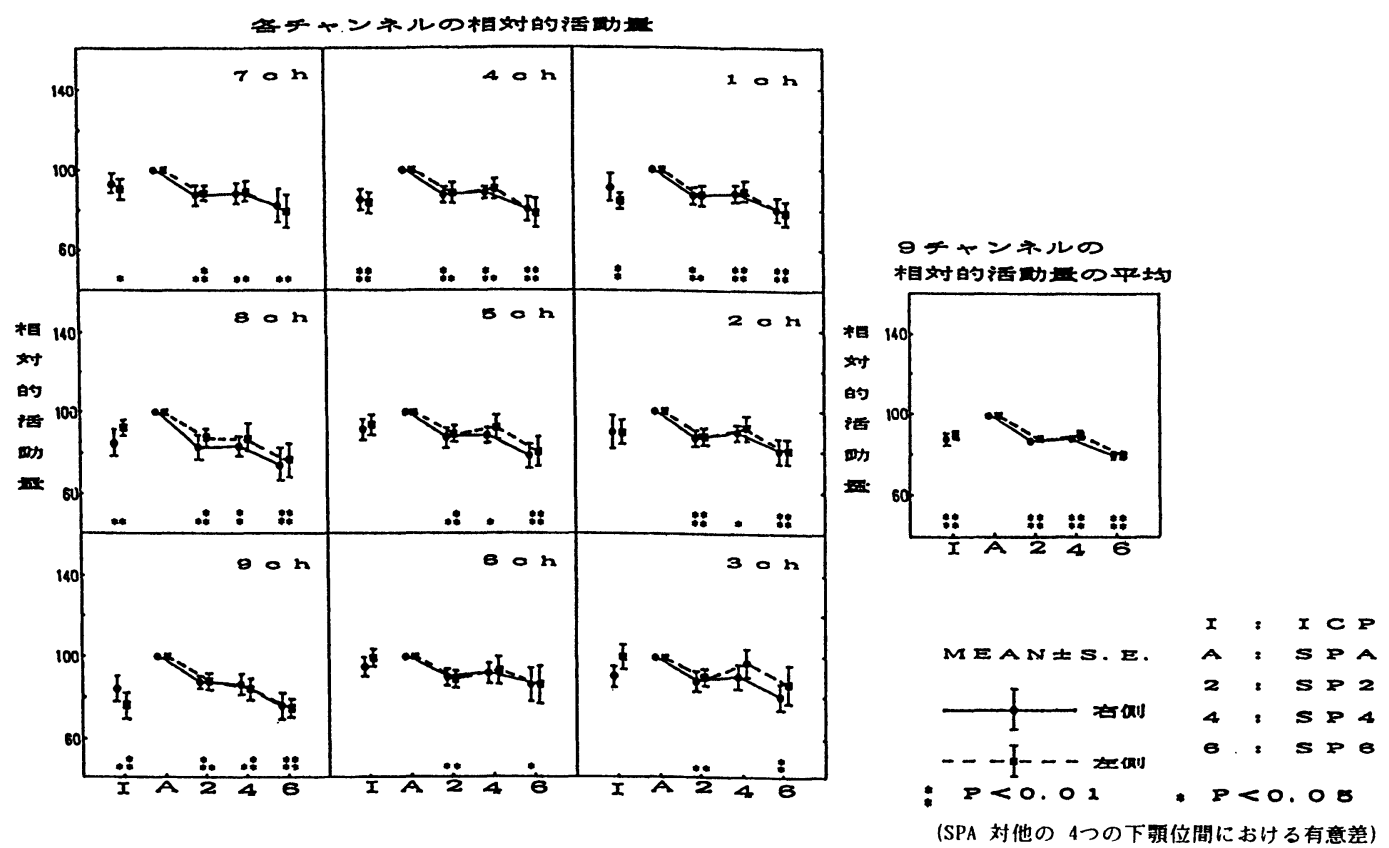

図10 機能性反対咬合者 8名のステージ I での相対的活動量

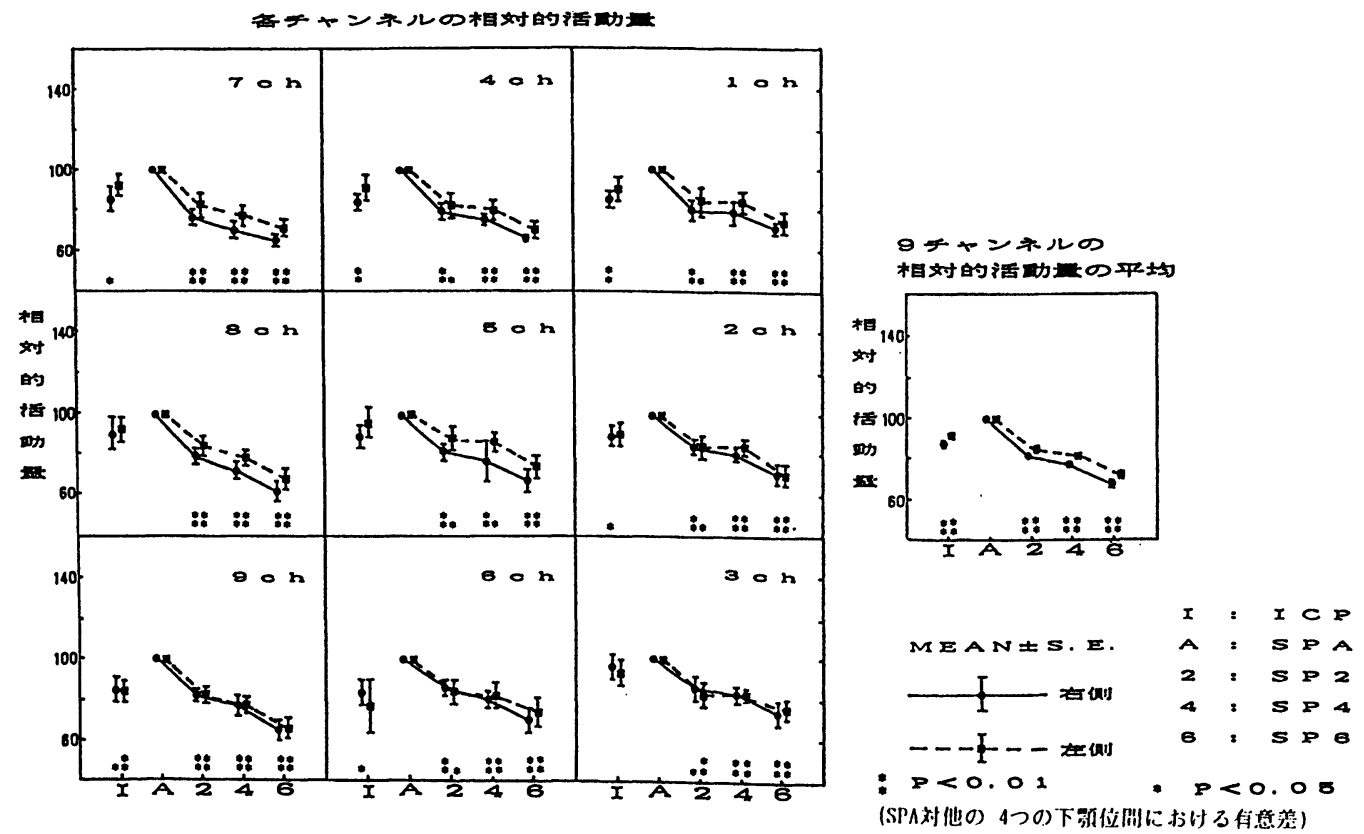

図11 機能性反対咬合者 8 名のステージIII での相対的活動量

という違いが認められた。これょり、小児正常 咬合者群に比べて成人正常咬合者群では、咬筋 筋活動を最大に発撣するための下頻位の許容範 囲か狭いことが推察された。

4.2 反対㕮合者
骨格性反対咬合者群では、ステージI、II 間 で下額位の变化に対する筀活動性に明確な差異 はなく、SPA からSP6 への変化の傾向は小児正 常咬合者群に類似していた。これは、骨格性反 対咬合者群の年令が小児正常咬合者群に類似し 
各チャンネルの相対的活動量

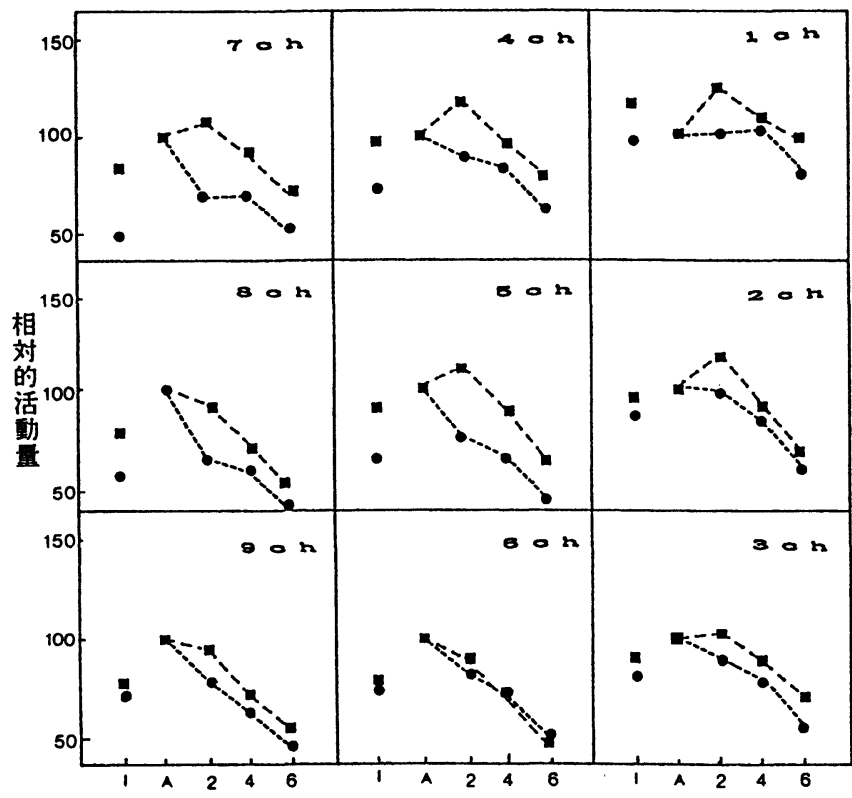

困12 譏能性反対咬合者：DのステージIIIでの相対的活動量

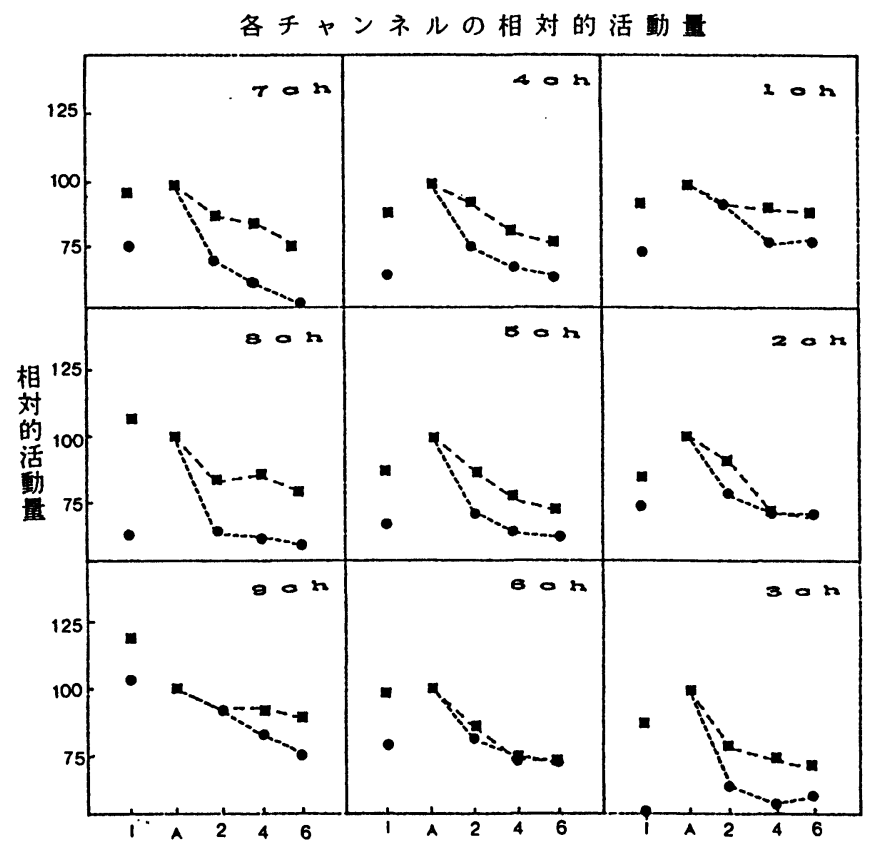

9 チャンネルの

相対的活助の平均
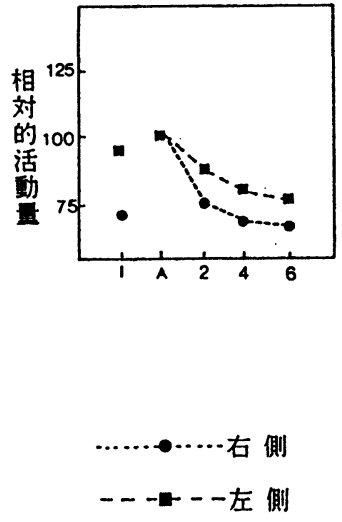

I : I CP

A : $S P A$

2: $S P 2$

4: $S$ P 4

6: SP 6

図13 譏能性反対咬合者：DのステージIIIから30日後での相対的活動量

ていることに加えて、骨格性反対咬合者群は反 対咬合ではあるが、咬頭嵌合位の偏位がないた めと考えられた。
機能性反対咬合者群のステージIでは、SPA からSP6までの下䫓位の中でSP2 で最も筋活動 量が大きいと言う特徵的な傾向を示しており、 
先の3群とは明らかに異なっていた。ここで、 スプリント作製時に咬合器上に装着した上下柬 列石票模型の所見から、機能性反対咬合者群の 咬頭嵌合位の水平的位置はSP2 の近傍あるい は、これよりも前方にあることが認められた。 一方、先の 3 群における咬頭嵌合位の水平的位 置は、SPAの近傍にあることが認められた。こ れより、機能性反対咬合者群と先の3群との咬 筋筋活動性の違いは、咬頭嵌合位の偏位による 影響が大きいと考えられた。

機能性反対咬合者群のステージIからステ 一ジIIIまでの筋活動量の変化では、スプリント 装着時の最大筋活動量を示す下影位が、ステ ー ジIからステージIIIにかけて、SP2 からSPA へと移って来ることが認められた。これは、ス テージIIにおいてはSPAでのスプリントを装着 することにより、さらにステージIIIでは被蓋改 善により、下頻の機能的前方偏位が除去され て、咬頭嵌合位が本来安定すべき下䫑位、すな わちSPA に近ずいたためと推察された。また、 ステージ II では治䖉開始前においても、スプリ ントにより機能的前方偏位を除去し、咬頭嵌合 位が本来安定すべきと考えられる下䫓位を新た に与えた場合、咬筋は最低7日間でこの新たに 与えた下硕位に、ある程度適応できる可能性を 示唆していると考えられた。

\section{3 リルートメントと発火頻度}

全ての被験者群の全チャンネルにおいて、最 小の筋活動量を示す下額位でも、最大筋活動量 の 60 パーセント以上の筋活動量を示すことが認 められた。一般に、ヒトの筇肉の中で母指外転 筋など比較的小さな筋では、最大筋活動量の 50 パーセントまでリクルートメントが生じ、50 パーセントから100パーセントまでの筋活動量 は、発火頻度の增加に依存することが知られて いる4!。そして、ヒトの咬筋においても、これ が当てはまる可能性のあることがGoldbergらら によって報告されている。これらのことから、 本実験結果では全ての下䫑位でリクルートメン トが完了していると推察され、各下䪽位間での 筋活動量の違いは発火頻度の違いによると考え られた。さらに、下額位の変化に対する筋活動 量の変化の傾向は、各被験者群の左右全チャン ネルが一定の傾向で变化したことから、一般 に、下頻位の变化に対して咬筋の全ての部位
で、同じ割合で発火頻度が変化することが推察 された。

本実験における相対的活動量の結果は、各被 験者群について平均値を表示したが、被辆者ご とに見ると下影位の変化に対する筋活動量の変 化の傾向が、チャンネル間で一定の傾向を示さ ないものが機能性反対咬合者群8名のなかに2 名存在した。図12に、このうちの1名（被䂆者 D) に打けるステージIIIの結果を示す。これら 2名では、ステージIからIIIまでを通して、下 頻位の変化に対する筋活動量の变化が、チャン ネル間でー定の傾向を示さなかった。そのため ステージIIIかららに30日以上経過した後に、

再度筋電図を記録した結果を図13に示す。この 時点では、チャンネル間で一定の傾向を示し小 児正常咬合者群に類似してくることが認められ た。

下頻位の变化に対する筋活動量の変化の傾向 が、各チャンネルで一定の傾向を示さない症例 か、機能性反対咬合者群にのみ2名認められた ことから、咬頭嵌合位が偏位している症例のな かには、下頻位の变化に対して咬筋の全ての部 位で同じ割合で発火頻度が变化しない場合があ ることが推察された。また、頻関節症を引き起 こす大きな原因の一つとして、咬頭嵌合位の偏 位が指摘されている6、7ことから、影関節症の 発生機序に発火頻度の变化が何らかの関係を もっているものと考えられる。したがって本筋 電図分析システムを用いて、咬頭嵌合位の偏位 のある不正咬合症例における額口胿系の機能障 客を、臨床的に診査できる可能性が示唆され た。

$$
\text { 5. まとめ }
$$

1)正常咬合者でも成人と小児では咬筋筋活動 性に差があり、小児に比べて成人では筋活動を 最大に発揮するための下額位の許容範囲が狭い ことが推察された。

2)骨格性反対咬合者群では、咬頭嵌合位の偏 位がないため、下顥位の変化に対する筋活動性 は、小児正常咬合者群に類似することが認めら れた。

3)機能性反対咬合者群の治㞠開始前では、下 䫑位の変化に対する筋活動性は小児正常咬合者 
群とは異なる傾向が認められた。しかし、咬頭 嵌合位の偏位を改善することにより、小児正常 咬合者群に類似した傾向を示すことが認められ た。

4)機能性反対咬合者群 8 名のなかの 2 名で は、ステージIからIII までを通して下頻位の変 化に対する筋活動量の変化が、チャンネル間で 一定の傾向を示さなかった。しかし、ステージ III からさらに30日以上経過した後に再度筋電図 を記録した結果、チャンネル間で一定の傾向を 示し小児正常咬合者群に類似してくることが認 められた。 
1)松野功, 他：20ch筋電因分析システムに よ了咬筋筋活動の研究。医用喂子と生体工 学, 27, 121-126, (1989)

2) $M \phi 11$ er, E.:The chewing apparatus, Acta Physiol. Scand., 69, Suppl. 280. $1-229,(1966)$

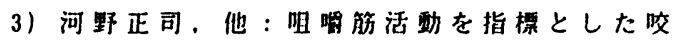

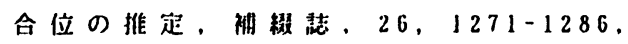
(1982)

4) Basmajian. J. V. and leluca. C. J.: Muscle Alive, (1985), Baltimore, WILLIAMS \& WILKINS.

5) Goldberg, L. J. and Derfler, B.:Relationship among recruitment order. spike amplitude, and twitch tension of single motor units in human masseter muscle, J. Neurophysiol., 40,879-890, $(197 z)$

6) 0keson, J. P.:Fundamentals of $0 \mathrm{cclu}$ sion and Temporomandibular Disorders, (1985), St. Louis, Mosby.

7) Ramfjord, S. and Ash, M. M.: OCCLUSION (1983), Philadelphia, Saunders. 